\title{
Expansion Strategies of a Departmental Commercial Company
}

\author{
Vargas-Hernandez $\mathrm{JG}^{{ }^{*}}$ and Zamudio Serrano LEAS ${ }^{2}$ \\ ${ }^{1}$ University Center for Economic and Managerial Sciences, Zapopan, Jalisco 45100, México \\ ${ }^{2}$ University of Guadalajara, Zapopan, Jalisco 45100, México
}

"Corresponding author: Vargas-Hernandez JG, University Center for Economic and Managerial Sciences, Zapopan, Jalisco 45100, México, Tel: 523337703340; Email: josevargas@cucea.udg.mx

Received date: May 29, 2017, Accepted date: July 20, 2017, Published date: July 27, 2017

Copyright: (c) 2017 Vargas-Hernandez JG. This is an open-access article distributed under the terms of the Creative Commons Attribution License, which permits unrestricted use, distribution, and reproduction in any medium, provided the original author and source are credited.

\begin{abstract}
The present work seeks to approach the strategies implemented by Coppel, a Mexican company that is competing in the department stores market. This research introduces us to the strategies that the company which is within the leaders in this sector has implemented to position itself as such. This is largely explained by the theory based on resources and capabilities. The method of study is based on the review of theoretical literature and similar case studies that have been successful. The analysis of the results presents and describes the acquisitions, as well as the process of internationalization that have been part of the positioning of the company.
\end{abstract}

Keywords: Acquisitions; Internationalization; Strategies; Family business

\section{Introduction}

The current national and international economic environment is characterized by a diversification processes of expansion and growth of companies, among other factors, by technological advances, telecommunications improvements, new financing systems, excess supply on the demand and acceleration of the product life cycle [1].

In the Mexican context, there are a large number of companies focused on the commercial stores which compete for the Mexican market. Within the strategies that companies have chosen for their expansion have been the strategy of opening branches throughout the national territory or acquisition of other companies that turn out to be key opportunities for their growth and presence in the country. Another of the strategies is the insertion in international markets, which are profitable and favor the growth of the company.

In this investigation it is approached such strategies taken by the Sinaloan company Coppel, SA of C.V., which have been the engine of the high growth and positioning of the company at national and international level.

The document is made up of the following sections. Initially, the background will be discussed, emphasizing the context of the company and its main competitors within the country, then the problem will be delimited, complemented by the justification. The fifth point will be the revision of the theoretical literature, presenting the main theories focused on the expansion and internationalization of a company, institutional theory and definitions of acquisitions and internationalization. The sixth point talks about the empirical literature. Later there is the contextual framework where it will talk about the company, continuing with the analysis of results of the strategies of the company, and finally it will be given a brief conclusion.

\section{Background}

The current economic environment is characterized by a process of globalization in which national and international borders have been eradicated in the face of political, social, cultural and technological advances. One of the first authors to use the term globalization was Levitt [2], alluding to the globalization of markets. These were in a process of production based on the product cycle, to another global markets. The FMI [3] defines globalization as the accelerated global integration of economies through trade, production, financial flows, technological diffusion, information networks and cultural currents.

Undoubtedly, in such a globalized environment companies are in need of changing their strategies to obtain greater growth. One of the most frequent strategies for companies to expand is geographically within their borders, creating competitive advantages and strengthening the structure of the company. Another of the strategies that companies take is internationalization, in which companies decide to go to other external markets to its original location, being understood as one of the most complex forms due to its growth and interaction with different cultures.

Mexican companies have not been the exception to lean for these types of strategies, seeking to grow, and position their brand. Within the Mexican context there are several companies dedicated to the commerce sector, which have grown geographically within the country through acquisitions and growing internationally. Some of the companies that have had the highest growth through these two strategies have been the companies focused on the department stores. This is the case of the study company of the present research.

The acquisitions and mergers favor the growth of companies. Within the Mexican context a favorable scenario is estimated for companies that opt for these strategies, since it is expected that by 2018 they will reach their maximum with 29.7 million dollars. Mexico occupies the fourth position among the nations that project the greatest growth in this activity in the next five years.

The company Coppel, is a company that has chosen to venture into the national market positioning its brand as one of the best within the 
country through the strategy of acquiring other companies. In addition to its growth has also encountered its competition, which manages similar products and payment options that are similar. The commercial sector to which Coppel is directed is highly competitive in the national and international market. In Mexico, Coppel has large competitors that compete for the same segment of the market, among which Group Elektra and Grupo Famsa stand out, being department stores that are focused on the middle class, but also competes with companies such as Liverpool, Sears and El Palacio de Hierro on certain items such as furniture or clothing [4].

Coppel is the nation's second-largest department store sales chain. It is a family business that is dedicated to the purchase and sale of furniture, household goods and clothing, as well as the granting of credits. It has presence around the entire Mexican Republic, in 482 cities, with greater concentration in the north of the country, as well as the metropolitan area $[4,5]$. However, it is in a competitive market in which different companies exist, part of which is their direct competition. They are in the same process of expansion in search of new markets and opportunities to acquire other companies, since, they are aware of the profits that are obtained when conducting a good negotiation, and the growth that can have the company either inside or outside the country as the case may be.

Within the country, the Federal Economic Commission for Competition (COFECE) is an autonomous regulatory body responsible for monitoring, promoting and guaranteeing competition and free competition in the markets, applying the law to prevent market structures that entail risks in competition through concentrations and promote a culture of competition, among other things. This body has been a major player in recent years in the field of acquisitions, as it has been found that it is necessary to punish some companies to exceed the concentration margin.

In recent years, Mexican companies have increased their activity abroad, through the internationalization of their companies, however, have not generated a major impact of growth in the economy of the country.

\section{Delimitation of the Problem}

Given the current characteristics of the Mexican market in terms of competition from department stores dedicated to retailing, it is important to analyze how they have impacted the acquisitions and internationalization of companies in their growth. Whereas each company has its own expansion plan based on the market they want to reach and are aware of the constant competition in which they are given to the diversification of expansion and growth processes.

Based on the previous analysis of this investigation it is proposed the following:

How has the growth of Coppel, S.A. Of C.V. The expansion strategies you have set in motion?

\section{Justification}

Given the current characteristics facing the country, it is necessary to diversify the strategies used by national companies to expand their market, which is why the main objective of this work is to have an approach to the strategies that have marked the success and diversification of a national family business, in a market as competing as that of department stores in Mexico. In particular, it is analyzed in detail from a theoretical point of view through an analysis of the literature, opportunities and strategies that the company has used, resulting in rapid growth in recent years.

The main idea is to analyze the expansion strategies that the company has taken in recent years, having in it different types of strategies that have placed it as one of the best companies at the national level, it is interesting to analyze the case of the present company. Despite the criticisms received by most of the family-owned companies due to their structure and their conservative trajectory, Coppel has been one of the exceptions, thanks to the diversification of its strategies and the change in its expansion policy an exponential growth.

Credit sale strategies are analyzed, which has represented part of the success of the firm, as well as the merger and acquisition strategy that have helped to have a greater presence of the company at the national level, in addition to its internationalization strategy to venture into markets of South America and finally the strategy of expansion in relation to the banks that are part of the company.

\section{Review of Theoretical Literature}

When wanted to define a family business, it finds it difficult to obtain an exact definition, which is why several authors have proposed definitions based on different factors. Most of the definitions are based on three aspects. Casillas, Díaz and Vásquez [6] develop them as follows to delimit and facilitate their understanding:

1. Ownership or control of the company: It is practically based on the percentage of participation that the family has in the total capital of the company.

2. The family's power over the company: it talks about the work that some members of the family do, talks about the executive positions occupied by the members of the company or the CEO is a member of the family.

3. The intention to transfer the company to future generations: it is the desire to maintain in the future the participation of the family in the company or the fact that future generations of the founder's direct descendants take control over the management or ownership of the company.

As it can be seen, there is no clear definition of the family business. In these aspects it is understood that the members of the family occupy executive positions, just as a member of the family can be the general director of the company, as is to be expected. In a family business one of the main objectives is for the company to grow and be directed by later generations, which will continue to seek the expansion of the company through different strategies.

A strategy can be understood as the implementation of actions to reach a specific purpose, in other words, a strategy involves an evaluation of the company in relation to a SWOT analysis, to know the company well and based on this to create competitive advantages, This analysis focuses on analyzing their strengths (F) and weaknesses (D) where the company can ask the question "where are we?, the desired growth levels wondering where should we be?, to answer this question is important to identify their opportunities $(\mathrm{O})$ and threats $(\mathrm{A})$ in the environment they encounter [7].

Strategic planning is understood as a process that requires the collection of internal and external information from the organization so that managers can see the future and develop the necessary actions to deal with it [8]. Within the different strategic options for which a company can choose to achieve its expansion objectives, it has the 
geographical diversification of the markets either inside or outside its national border [9].

Geographic diversification strategies are the options chosen by most of the family businesses, starting geographically growing at the national level having presence in most of the states of the Republic or in a certain region, thanks to the opening of branches and acquisitions that are made from other stores and subsequently choose to grow outside their borders through internationalization. Another of the strategies they can take is to diversify their market by entering a new one or to benefit their company by offering different services to their customers.

Family companies are characterized by strengths indicated by the literature that can lead to identify the competitive advantages of organizations in their expansion processes either within their country or internationalize.

The theory of resources and capabilities studies the development and implementation of corporate strategies, which include the geographical diversification of markets or the internationalization of the company. The intangible resources of a company are considered the origin of competitive advantages in the destination markets, finding that certain strengths of the family companies can be considered as intangible resources generating the competitive advantages in its strategy of internationalization [9].

In line with the above, Vargas-Hernández et al. [10] argue that the theory based on dynamic resources and capacities can become an approach to strategic management that contributes an important part to evolving science of the organization. Penrose [11], creates the fundamentals of the theory and describes the processes by which a firm grows, conceptualizing it as a set of productive resources with administrative organization, also analyzes the growth of the company with an emphasis on its internal resources and how they are managed, arguing that the constraint restricting the growth of the company is given by the capabilities of the current management.

Following the work of Penrose, other authors have emerged that complement their contribution, such as Teece [12], who extends the contribution, noting that companies have an excess of resources, which can be used for diversification purposes. On the other hand, Wernerfelt [13] refers to companies as a broader set of resources to balance the exploitation of them and the development of new ones. Barney [14] suggests that when the implementation of a strategy requires the acquisition of resources, a strategic market is developed, these markets are where companies buy and sell the resources necessary to implement its strategy, so when companies wish to implement a product diversification strategy, they may choose to do so by acquiring other companies.

\section{Acquisitions}

There are several authors that define this concept as they are VargasHernández et al. [10] assert that acquisitions are transfers of control of operations and the administration of one company, which is the goal, to another, which is called an acquirer, which makes the former a unit of the latter. For his part Pérez [15], defines it as a company that buys or acquires another, or a part of a company, without losing its main characteristics. It is a direct negotiation, in which one firm buys the assets or shares of another and in which the shareholders of the acquired company, cease to be the owners of the same.

Peng [16] divides mergers and acquisitions (F \& A) as follows:
1. F \& A Horizontals: are those that involve companies competing in the same industry.

2. Vertical F \& A: those that involve suppliers and/or buyers

3. F \& A Conglomerates: involve firms in unrelated product industries.

4. F \& A Friendly: refers to those that the directive and management of an objective firm agree with the transaction, and

5. F \& A Hostiles: those that are carried out against the wishes of the board and the management of the target firm, which reject the offer of F \& A.

\section{Internationalization theories}

Based on internationalization, several definitions have emerged, such as Haro et al. [17] who define internationalization as the set of operations that facilitate the links between companies in international markets. It is a process where the growing involvement and international projection of the organizations is observed. In other words, internationalization is understood as the process by which companies opt for an international geographical expansion strategy, through an evolutionary process, where the objective is to enter a new market, to have lower production costs, to acquire new technology and a more efficient distribution of the company.

There are different perspectives regarding internationalization. Several authors agree that there is no exact definition, because internationalization in each company is a different process, depends on aspects such as the context in which it is, the sector to which it belongs and the objectives of this. It is for this reason that it is necessary to know the theories that have arisen around internationalization. Buckely and Casson [18] focus on the theory of internationalization, explaining why transactions of intermediate products between countries are organized by hierarchies instead of being determined by market forces.

Within the theories is the eclectic paradigm of Dunning [19], where it explains how the extension, the form and the pattern of international production of a firm, are based on the competitive advantages of the company, the propensity to internationalize external markets and the interest of producing in them. Another relevant one is the macroeconomic approach to Vernon [20] approach, explaining why countries perform FDI, based on neoclassical models of the international model to explain the company's production patterns.

The Uppsala model is an approach that emerges in the process of internationalization that differs from the previous ones, since, it analyzes the internationalization as a gradual process in which the company initiates operations in the national market where internationalization occurs as a result of a series of activities that take place abroad in a series of successive stages [21]. On the other hand, there is a recent approach, Born Global theory, which is understood as companies all those companies that are internationalized since they are created or do during their first two years of existence.

\section{Empirical Review}

Within the empirical review it is analyzed some cases of success of companies that have acquired others to increase their growth, as well as companies that have opted for internationalization. Within the food sector Grupo Bimbo has been the fastest growing company in its sector in Mexico, due to the various acquisitions that it has achieved, positioning it as one of the best, besides having a presence in other 
continents. In 2015 acquired the Canadian company Canada Bread and Saputo Bakery.

Another of the big companies is Alsea who in 2015 made a big purchase acquiring Vips and Grupo Zena, through these acquisitions, the company estimated a sales growth of $20 \%$ during that year.

In the departmental department store, a very recent and very sound case was the acquisition of Suburbia by Liverpool. Both are department stores and the difference is that they are targeting a different sector of the market. The acquisition had a final value was the acquisition target is part of Liverpool's expansion to take a larger stake in another segment of the market, to which Suburbia belongs, with potential growth of 15 percent per estimate.

On its turn, there are Mexican companies that have internationalized such as the case of

Cinépolis that has its headquarters in the city of Morelia, Michoacán, and has cinematographic complexes in Mexico, El Salvador, Costa Rica, Colombia, Panama, Brazil, Peru., India, Honduras and the United States. Teléfonos de México, S.A. Of C.V. (TELMEX), a Mexican telecommunications company based in Mexico City. It offers its service in Mexico, Latin America and the United States. Mabe, is a multinational company that designs, produces and distributes appliances to more than 70 countries around the world, the company is stable in Mexico City.

\section{Contextual Framework}

Coppel is a Mexican company founded in 1941 in the city of Culiacán, Sinaloa, by Luis Coppel Rivas and his son Enrique Coppel Tamayo. It all started when Don Luis Coppel Rivas and his son decided to move from the city of Mazatlán to Culiacan, Sinaloa to establish a store that was called "The Gift" that eventually ended up selling watches. Thanks to the experience acquired over the years they were able to realize the economic difficulty that the population had to face cash payments. After World War II, liquidity was not abundant in families. It is at this time that father and son decide to invest all their capital saved to sell furniture on credit in comfortable weekly installments. Thus, relying on the word of the client turned the Gift into a furniture store with credit system and that's when it adopted the name of Coppel, because it was the name with which the customers identified the company.

Shortly thereafter they were completely dominating the sector and it was there that they began to introduce new product lines and new sources of financing. The growth of Coppel has been enormous, part of it can be seen with the number of stores with which it counts nationally and internationally and with the diversification of its products, selling appliances, furniture, footwear, clothing, toys, perfumery, cell phones, electronics and computers, tires to name a few.

In 1956, El Regalo became Coppel's Branch, extension of Comercial Coppel, S.A. In 1961 the third Coppel Escobedo store was opened as Mueblera Coppel, S.A. Which would later be merged with Comercial Coppel S.A. With a duration of 20 years, later in a meeting with the Extraordinary General Shareholders' Meeting in 1979 was transformed into Almacenes Coppel S.A. Of C.V. It did not last long with that name, since, in 1992, it changed its name to Coppel S.A. Of C.V., commercial name with which it is known at the moment and is the largest departmental store of the country. In 1989 it had 22 stores, sales of 100 million dollars and 1800 employees. Until this year the firm had a policy of conservative expansion, in 1990 the company decided to change its policies by opting for an expansion plan, resulting in a 10fold increase in results in just 13 years.

In 2002 it made its first acquisition to expand its products. It acquired Shoemakers Canada. In 2003 it had 210 stores, sales of more than 1 billion dollars and 19000 employees in payroll, for 2006 it opens 93 stores. In May of this same year it started with a new company in a different sector in which it was competing, entering the financial sector, a sector that went hand in hand with its company to have a large number of employees entering the Afores sector with its own company Afore Coppel. In 2007 BanCoppel was born.

Shoe stores Canada have not been the only company that has been acquired to expand its brand and have a greater presence in the national territory. In 2015 it acquires Viana stores. The company has been visionary and its market is not only in Mexico, since in 2009 it penetrated in the international market opening branches in Argentina and Brazil.

Coppel's main characteristic has been the ease and speed in obtaining credit for its clients, a key strategy for its success, showing that more than 5 million Mexicans have applied for credit at one of the branch offices in the firm [22]. It is a company that focuses on the lower middle class, that is why the success of its credit, by giving customers the facility of obtaining credit and affordable payment options.

Part of the success and growth of the company has been based on the standardization of its processes. In the words of Agustín Coppel Luken, president of Grupo Coppel's Council and director of the company,

"We focus everything to become a standard and efficient model, construction, trucks, distribution centers, store design, exhibition, all very focused on repetition and standardization. The same tube of light is in one store and in the other, the same constructive method, the same boards of electricity, the same floors, that gave us an efficiency and a way of being able to attend to all. If we found better ways of doing things, we implemented them nationally" expressed in an interview with Takahashi [23].

Part of the philosophy of the founder, Don Enrique Coppel, is that every person has the right to credit as long as it does not prove otherwise. If a non-paying customer is asked to return the item, it is a policy that is still valid within the company. As mentioned the ease of obtaining the credit within the company is a process different from the one carried in banks, however, the number of unpaid loans is within $5 \%$, a figure similar to the average of the banks.

Correct decisions by its managers have managed to position itself within the best companies in the country, as a consolidated company and growth plans in the short and long term, following a vision from the beginning, regardless of whether a store is find near the other, the main idea is that it is in a strategic place.

Table 1 shows the ranking of the 10 most important retailers in Latin America, finding the Sinaloa company among the most important ones having until 2013 revenues of $\$ 6.304$ billion. According to the Deloitte consulting firm in the 18th edition of its annual report "Global Powers of Retailing 2015", Coppel together with the Mexican Northern group from Monterrey, Fomento Económico Mexicano (FEMSA) are among the 50 global retailers that have grown faster on the period from 2008 to 2013. In addition, Coppel occupies the 30th place in the list obtaining a growth rate in revenues of 17 percent in the mentioned period. 
Page 5 of 6

Within this same edition in the global ranking of the world's top 250 retailers, FEMSA has achieved a scale of 10 places, going from 144 in 2012 to 134 in 2013. Coppel has increased 31 places. It was ranked 180 in 2012 and in the last edition of 2016 it ranked 149 [24].

\begin{tabular}{|c|c|c|c|c|}
\hline $\begin{array}{l}\text { Ranking } \\
\text { (2013) }\end{array}$ & $\begin{array}{l}\text { Ranking } \\
\text { (2012) }\end{array}$ & Company & País & $\begin{array}{l}\text { Income } \\
\left(2013^{*}\right)\end{array}$ \\
\hline 47 & 51 & Cencosud & Chile & 19,855 \\
\hline 88 & 97 & S.A.C.I. Falabella & Chile & 11,377 \\
\hline 127 & 124 & Soriana & México & 8,240 \\
\hline 134 & 144 & FEMSA & México & 7,655 \\
\hline 149 & 180 & Coppel & México & 6,304 \\
\hline 150 & 162 & Lojas Americanas & Brasil & 6,247 \\
\hline 176 & 191 & Chedraui & México & 5,157 \\
\hline 177 & 201 & Liverpool & México & 5,156 \\
\hline 241 & 212 & SMU & Chile & 3,823 \\
\hline 247 & ${ }_{-}^{* *}$ & Magazine Luiza & Brasil & 3,758 \\
\hline \multicolumn{5}{|c|}{$\begin{array}{l}{ }^{*} \text { Millions of Dollars. } \\
\text { **Does not appear on the ranking. } \\
\text { Source: Deloitte (2015). }\end{array}$} \\
\hline
\end{tabular}

Table 1: Top 10 more important retailers in Latin America.

By 2015, Coppel stores had 1,149 points of sale, of which 767 are full format (the department store), 380 Coppel Canada shoe stores and two Coppel Digital stores, which is a format in development that is expected to have up to 300 Shops. Besides, it has presence in 442 cities of the country, being in all the states of the Republic.

Currently, Coppel stores have a $62.4 \%$ participation in the variety stores sector and $80 \%$ of its sales are on credit. One of the main challenges that the company has as a result of globalization is to get its customers to make purchases online with their credit systems through the Coppel bank [25].

\section{Method of Investigation}

In this research a descriptive method is used based on the literature review, starting from the main concepts of acquisition, merger and internationalization, these being the strategies followed by Coppel S.A. Of C.V. over the years to achieve the success and positioning of the company [26]. It is also analyzed the statistical data presented by institutional bodies in which the positioning of the company is signaled worldwide, as well as the amounts that have invested the firm in the acquisitions it has obtained for its expansion.

\section{Analysis of Results}

Coppel's national expansion strategies, as well as its international expansion strategy have helped in the growth and strengthening of the firm. The literature on the company tells us about acquisitions by the company towards other companies where some of them were part of their competition and favored in the presence of the Sinaloan company in the central region of the country. Another of its acquisitions was relevant due to the products they sold increasing the diversity of products offered by the company, as well as the use of facilities.

Once the expansion of the company started, it focused on having a greater presence in other states outside of their state of Sinaloa [27]. One of the first actions by the company was the acquisition of "Shoemakers Canada" in 2004, being one of the favorite companies in the footwear market, but that had been dragging some financial problems. Coppel took the opportunity to acquire the 180 stores it had in Mexico and 15 in the United States benefiting from the infrastructure to create its distribution points and boost its sales, and acquired the most modern footwear manufacturing plant in Mexico in that year.

The agreement was made through a contract in which Coppel participated with the Azaléia Group of Brazil, which is among the five most important footwear manufacturers in the world [28]. Said agreement left the Mexican company as responsible for the commercial operation and Azaléia would take care of the production, although also would be bought footwear to other manufacturers. The union of Coppel and Shoemakers Canada resulted in the store that is now known as "Coppel Canada", this merger was positive for the shoe store because the scope of distribution with Coppel is stronger, and the standards are still maintained quality, good prices accompanied by the ease of purchase on credit thanks to Coppel's payment options. Undoubtedly the acquisition of Canada allowed the Sinaloa company to take a very strong leap by positioning itself among the top shoe stores in Mexico.

Another strategy chosen by the company has been the incursion into other markets that in turn are linked to their company with the idea of offering greater services to its customers, entering the financial market with the opening of its own bank, "BanCoppel "And" Afore Coppel ". The first one was born in 2007, with the aim of improving the management of loans granted to clients and at the same time performing the role of bank for another segment of the market, focused on the low income population [29]. By 2014, BanCoppel had 850 branches and more than 9,500 employees with a projection to grow more. Afore Coppel arises to manage the economic resources of the clients to offer them a pension in the moment of their retirement, today it is within the best Afores of the country.

In 2009, the company began its international expansion process by entering the Latin American market, starting operations in Argentina, with 2 stores in Buenos Aires and Brazil and with 2 stores in Rio de Janeiro, the latter being one of the most important markets in South America. Although at first it was not easy for the company to adapt to the cultures and customs of these countries trying to transplant the Mexican model, it has managed to get ahead adapting its strategies to the needs of the market. In addition, Coppel finances to a segment of the population that, otherwise would not have access to credits.

Currently the Sinaloa company has 14 stores in Brazil, mainly in Curritibia and 14 more in Argentina, but finds an opportunity to expand its operation in South America thanks to the Alliance of the Pacific, with Chile, Colombia and Peru being the ideal markets in its expansion by South America.

The second acquisition by the company was a very sound case, as the firm acquired a department store of the same sector that was part of its competition in the center of the country. In 2015, Coppel stores acquired Lojas Viana, investing 2,500 million pesos in the purchase and conversion of 51 points of sale in Viana, ending with a 60 year history. With this acquisition Coppel increased its number of stores by $4 \%$ and 
Page 6 of 6

a $6 \%$ increase in square meters of sales floor in the country, where it increased from 30 to 48 points of sale and increased its presence in the center of the country and in the Metropolitan Zone in cities like Puebla, Querétaro, Veracruz, Cuernavaca, Toluca, Leon and Acapulco.

The objective of the company was to reach the center of the country, with this merger increase its presence in Mexico City where they had about 52 stores and with the acquisition of Viana duplicate its presence in this city, not only obtained points of sale, but the strategy provided to the company what would have taken in 12 years to achieve 30 stores because of the difficulty of the requirements of the area.

The company has been opening about 90 to 100 points per year in the three formats of store that it employs that are: complete format (the departmental store), shoe stores Coppel Canada and Coppel Digital. The strategies analyzed have been part of the growth and positioning of the company nationally and internationally, placing it as one of the best companies in Mexico, as well as being a family company that is not listed on the Mexican Stock Exchange. The only shareholders of the company are five, who are family members.

\section{Conclusions and Recommendations}

Family companies have a number of strengths that come to be considered as sufficient reasons to develop their national and international expansion. Based on the theory of resources and capabilities, intangible resources are often considered as a source of competitive advantage, this advantage is based on the human resources of the company, having the experience and knowledge in the business. This competitive advantage was the one that managed to identify Coppel for its expansion inside and outside the country. Within the departmental stores market there is still potential growth given the population growth and dynamism that characterizes the cities.

The high growth of the company is the result of a change within the internal policies because they were conservative. This change led to the implementation of expansion strategies which implemented the company by studying its competition and delimiting the needs of consumers. Knowing the sector to which most of its sales are directed, facilitating the payment methods has been one of the main characteristics of the company, combined with the acquisitions of other large companies benefiting from infrastructure, strategic points of sale and a greater positioning in the market.

The international geographical diversification of the company has succeeded in positioning it as an internationalized Mexican company characterized by a high growth potential in the Latin American market, where it is expected that in the coming years it will continue to grow and be present in other countries. The main objective of the company has been to increase its presence and to dominate in the market, objective that has been fulfilled thanks to the strategies implemented.

\section{References}

1. Cañas L, Fuentes G, Vallejo MC, Sánchez S (2000) Elementos determinantes del proceso de internacionalización en la Empresa Familiar. I. Congreso Nacional de Investigación sobre la Empresa Familiar, Instituto de Investigación de la Empresa Familiar, Valencia, España, pp: 401-417.
2. Levitt T (1983) La globalización de los mercados. Harvard-Deusto BusinessReview 4: 49-64.

3. FMI (1997) World Economic Outlook. Washington, DC.

4. Coppel SAdeCV (2011) Primera Revisión de Calificaciones de Corporativas y Programa de CEBURS de corto plazo. Calificación Corporativa.

5. Coppel SAdeCV (2013) HR Ratings ratificó la calificación corporativa de corto plazo de "HR1" de Coppel. Comunicado de Prensa.

6. Casillas JC, Díaz C, Vásquez A (2005) La gestión de la empresa familiar. Thomson, Madrid.

7. Peng M (2012) Estrategia Global.

8. Morales JSL, Ridaura IO (2016) Presencia de la expansión internacional en la misión y visión de las principales empresas privadas y estatales de América Latina. Estudios Gerenciales 32: 269-277.

9. Lombardo GF, Martos MCV, Jiménez RM (2007) Factores a tener en cuenta en la expansión internacional de la empresa familiar. Investigaciones Europeas de Dirección y Economía de la Empresa 13: 75-96.

10. Vargas-Hernández JG, Guerra García E, Bojórquez Gutiérrez AF (2014) Gestión Estratégica de Organizaciones.

11. Penrose ET (1959) The theory of growth of the firm. New York: John Wiley \& Sons.

12. Teece DJ (1982) Towards an economic theory of the multiproduct firm. Journal of Economic Behavior \& Organization, pp: 39-63.

13. Wernerfelt B (1984) A resource-based view of the firm. Strategic Management Journal 5: 171-180.

14. Barney J (1991) Firm resources and sustained competitive advantage. Journal of Management 17: 99-120.

15. Pérez Ramírez R (2013) Privatizaciones, fusiones y adquisiciones: las grandes empresas en México. Espacios públicos 16: 113-140.

16. Peng M (2010) Strategies at the Corporate Level. Global Strategy, pp: 253-288.

17. Haro C, Gandara JM, Rastrollo MA, Mondo T (2014) La internacionalización en las cadenas hoteleras. Estudios y Perspectivas de Turismo 23: 626-644.

18. Buckely PJ, Casson M (1999) A theory of international operations. J European Research in International Business. Amsterdam, North Holland.

19. Dunning JH (1988). The eclectic paradigm of international production: a restatement and some possible extentions. Journal of International Business Studies 19: 1-31.

20. Vernon R (1996) International investment and international trade in the product cycle. Quarterly Journal of Economics. Cambridge.

21. Johanson J, Wiedersheimpaul F (1975) The internationalization of the firm - Four swedish cases. Journal of management studies.

22. Smith E (2017) Coppel.

23. Takahashi H (2015) Página no encontrada. Forbes.

24. Deloitte (2016) Las potencias globales del comercio detallista 2016, como navegar en la nueva brecha digital. Recuperado.

25. Salop R (2012) Platicando con Enrique Coppel Luquen.

26. Coppel (2017) Acerca de nosotros. Recuperado.

27. Expansión (2015) Las 500 empresas más importantes de México de expansión 2015. Expansión, en alianza con CNN.

28. Academia Europea de Dirección y Economía de la Empresa. Vigo, España.

29. Mundo HK (2015) Coppel y FEMSA lucen en ranking global de retail. El Economista. 